\author{
Sergij Posokhov \\ (Uniwersytet Narodowy w Charkowie)
}

\title{
Университетская юбилейная культура на Востоке Европы
}

\author{
Culture anniversaries university in Eastern Europe
}

STRESZCZENIE:

Artykuł został poświęcony różnym formom autoprezentacji uniwersytetów w Europie Wschodniej. Szczególna uwaga została skierowana na tzw. kulturę jubileuszy uniwersyteckich. Okazało się, że na wschodzie Europy zjawisko to pojawiło się pod wpływem tradycji istniejących na starych uniwersytetach zachodnioeuropejskich. W okresie sowieckim obchodzenie jubileuszy na uniwersytetach uległo poważnej transformacji. Odrodzenie wielu form autoprezentacji w czasach współczesnych uwarunkowane było wieloma czynnikami. Wśród nich można zauważyć wiele cech różnicujących, co może wskazywać na kryzys w środowiskach uniwersyteckich.

Słowa kluczowe: uniwersytet, jubileusz, Europa Wschodnia, Związek Sowiecki

Характеризуя культурные импульсы, которые исходили и исходят от университетов, некоторые исследователи отмечают присущую университету «неизменную экстравертность» ${ }^{1}$. Действительно, за довольно длительную историю, университеты выработали разнообразные формы саморепрезентации. Многие университетские ритуалы и символы, направленные на окружающее общество, пришли из Средневековья, культура которого была ориентирована на невербальное общение. В этом случае церемонии и ритуалы были в числе наиболее важных символических форм общения. Имея различные функции, они, прежде всего, отражали существующий порядок, ие-

${ }^{1}$ П. Ю. Уваров, Университеть Российской империи глазами медиевиста (в защиту «идола истоков»), „Диалог со временем" 2001, nr 7, s. 215. 
рархию и властные отношения. Но они, безусловно, также формировали образ самого университета, производили впечатление на многих людей (и входивших в университетскую корпорацию, и из внеуниверситетской среды).

Академические шествия, торжественные богослужения, использование мантий и академических регадий, исполнение соответствующих музыкальных произведений, присутствие почетных гостей на университетских торжествах - все эти церемонии и культурные формы достаточно давно укоренились в практике европейских университетов $^{2}$. Не позже, чем в конце XVII века, характерным элементом мероприятий по случаю университетских торжеств стало сооружение триумфальных арок из дерева или папье-маше, с искусственными аллегорическими декорациями ${ }^{3}$.

Чтобы быть «понятыми», университеты Восточной Европы, уже с момента своего создания, также начали применять самые разнообразные формы такой саморепрезентации, прежде всего во время всевозможных праздников. Они показывали свои музеи и кабинеты местной публике, декларировали свои цели через «актовые речи» профессоров, приобщали к университету родителей во время публичных экзаменов, демонстрировали свои ритуалы и традиции, университетская библиотека по сути приобрела публичный характер и т.д.

Важную роль в такого рода культурных практиках стали играть юбилеи университетов. Наскодько можно судить из имеющихся источников, впервые юбилей университета был отпразднован в 1578 г. Поводом стало 100-детие Тюбингенского университета. В 1602 г. такой же юбилей отпраздновал Гейдельбергский университет. С этого времени постепенно формируется университетская юбилейная культура ${ }^{4}$. Причем нормой юбилейных мероприятий станет участие в церемониях многих горожан 5 . В XVIII веке после определенной поиосы критики все эти торжественные формы саморепрезентации переживают период возрождения на новых идейных основаниях и в ряде случаев приобретают дополнительную публичность. В частности, в это время еще более пышно некоторыми европейскими

${ }^{2}$ R. Ditzhuyzen, Selbstdarstellung der Universität. Feiern und Zeremoniell am Beispiel der Doktorpromotionen, [w:] Universität im öffentlichen Raum, Basel 2008, s. 49-50.

${ }^{3}$ T. Becker, Jubiläen als Orte universitärer Selbstdarstellung. Entwicklungslinien des Universitätsjubiläums von der Reformationszeit bis zur Weimarer Republik, [w:] Universität im öffentlichen Raum, Basel 2008, s. 88.

${ }^{4}$ Ibidem, s. 83-87.

${ }^{5}$ Ibidem, s. 87-88. 
университетами стали отмечаться их юбилеи. Так, празднование 200летия Дейденского университета в 1775 году продолжалось два дня и вкдючало торжественные молебны, музыкальные представления, речи и фейерверк. Праздник привлек так много зрителей, что в городе просто не было свободного местаб.

Собственно первыми выраженными формами саморепрезентации университетов Российской империи стали торжественные инаугурации в момент открытия университетов, во многом являвшие собою подражания европейским торжествам подобного рода. Примером для российских университетов стала инаугурация в 1737 г. Гёттингенского университета. Этот праздник, с помощью которого новый университет торжественно объявил о себе остальному ученому миру, прошел с большой помпой и роскошью: были отчеканены памятные монеты, прозвучали речи профессоров, была исполнена кантата, специально написанная для этого композитором Г.Ф. Телеманом и т.д. Отчеты современников об этом празднике были напечатаны во многих брошюрах и периодических изданиях ${ }^{7}$.

Инаугурация Московского университета состоялась 26 апреия 1755 г. и имела много общего с приведенной выше церемонией в Геттингене 8 . Праздник включал модебен преподавателей и учащихся в церкви Казанской Божьей Матери (напротив первого здания университета) и торжественный акт, на который были приглашены «знатные московские особы», родитеди учеников, именитые купцы, иностранцы, и где были прочитаны речи. Кроме этого, как писал С.П. Шевырев, «Русское угощение не миновало гостей, приглашенных на праздник. Илдюминация привлекла особенно народное любопытство. [...]. Цедый день и почти всю ночь, до четвертого часа по полуночи, несчетное число народа теснилось около Университетского дому» ${ }^{9}$. Подробное описание торжеств было помещено в газете «Санкт-Петербургские ведомости» (№ 39). В память основания университета была отчеканена медаль художником Ж.А. Дасье, на которой, среди прочего, были изображены здание университета и симводы наук.

Создатели второго в Российской империи Дерптского университета также стремились во всем подражать лучшему на то время не-

\footnotetext{
${ }^{6}$ R. Ditzhuyzen, op.cit., s. 60.

${ }^{7}$ А. Ю. Андреев, Российские университеть XVIII-первой половины XIX века в контексте университетской истории Европь, Москва 2009, s. 237.

${ }^{8}$ Московский университет в воспоминаниях современников, Москва 1989, s. 36-37.

${ }^{9}$ С. П. Шевырев, История Московского университета, написанная к столетнему его юбилею. 1755-1855, Москва 1998, s. 19.
} 
мецкому университету ${ }^{10}$. 21-22 апреля 1802 г. состоялась церемония инаугурации университета, которая включала торжественную процессию, акт с речами профессоров, вручение студентам матрикул и трапезу ${ }^{11}$.

Торжественное открытие Харьковского и Казанского университетов (соответственно, в 1805 и 1814 гг.) нескодько отличалось между собой, но все также свидетельствовало о попытке подражать «европейским правилам». Приведем примеры из истории Харьковского университета. Он был открыт 17 января 1805 г. Церемония была приурочена к общему собранию дворянства губернии. Торжества продолжались три дня и включали торжественные процессии, молебны, речи попечителя, епископа и профессоров (на латинском, русском и французском языках), вручение от имени императора шпаг первым студентам, иллюминацию, бал, обеды и гуяяния. Университетские архитектор и художник потрудились над изображением «Храма Славы», а университетский преподаватель музыки сочинид по этому случаю ораторию (при ее исполнении общее количество музыкантов и хора достигло 81 человека ${ }^{12}$ ). На все торжество была ассигнована сумма до 4 тыс. руб. ${ }^{13}$ Сохранилось довольно подробное описание этого «церемониального обряда» ${ }^{14}$, который был составлен проф. И.Ф. Тимковским на основе проекта В.Н. Каразина ${ }^{15}$, но очевидно, что его авторы были несамостоятельны в основных идеях. (Полагаем, неслучайно, И.Ф. Тимковский и позже, говоря об идеалах, упоминал Иену, Галле, Гёттинген $\left.{ }^{16}\right)$. Руководили процессом два церемониймейстера, которые были избраны из иностранцев (по всей видимости, это были адъюнкты И. Ланг и Н. Паки-де-Совиньи). По словам историка Харьковского университета Д.И. Багалея, «университетские деятели, со своей стороны, постарались сделать все, чтобы празднество вышио возможно эффектнее, торжественнее» ${ }^{17}$. Он также отметил,

\footnotetext{
${ }^{10}$ А. Ю. Андреев, op.cit., s. 364.

${ }^{11}$ Е. В. Петухов, Императорский Юрьевский, бывший Дерптский, университет за сто лет его существования (1802-1902), t. 1, Юрьев 1902, s. 101-103.

${ }_{12}^{12}$ Й. М. Миклашевський, Музична і театральна культура Харкова XVIII-XIX ст., Київ 1967, s. 150.

${ }^{13}$ Д. І. Багалій, Вибрані твори, t. 3, Харків 2004, s. 212-213.

14 Этот термин использован в официальной информации об инаугурации. Zob. Периодическое сочинение об успехах народного просвещения, С.-Петербург 1805, nr 12, s. 504.

${ }_{15}$ Zob. Д. И. Багалей, Харьковские университетские торжества, Харьков 1892, s. 14; idem, Вибрані твори, t. 3, s. 211-222.

${ }^{16}$ Д. І. Багалій, Вибрані твори, t. 3, s. 853.

${ }^{17}$ Ibidem, s. 212.
} 
что «собрание публики обоего пола было очень многочисленное и ее удоводьствие усугубляло торжество, во все время которого и посторонние знатные лица задавади пиры и угощения» ${ }^{18}$. Действительно, стечение публики на торжества было значительным, как и тот эффект, который был на нее произведен. Так, воспоминания донесли до нас следующую оценку этого события: «Когда отец возвратился из Харькова, с торжества при открытии университета, то рассказывал об этом с таким энтузиазмом, говоря о произнесенных речах, о блестящих надеждах для общества от просвещения (вообще же он был задумчив и молчалив), что я, слушая его, ощущал будто меня окружало какое-то обаяние...» ${ }^{19}$. После этого события члены университетского совета были озабочены разработкой проектов медади «в память открытия университета» ${ }^{20}$. Даже спустя пятьдесят лет после инаугурации профессор А.П. Рославский-Петровский отмечал, что «многие из украинских старожилов доселе живо вспоминают как о внешнем блеске праздника, так и о произнесенных, по случаю его, красноречивых речах» ${ }^{21}$. Как отмечал Д. И. Багалей: «Это не было официальное открытие нового учебного заведения. Это был настоящий «праздник просвещения» для города, для всей Украины и даже для «полуденного» края России» ${ }^{22}$. Это было первое в Украине нового времени массовое действо, поистине народная манифестация, настоящий праздник просвещения.

Алгоритм саморепрезентации университета, заданный инаугурациями, продолжал действовать и в дальнейшем. Собственно, момент торжественного открытия в ряде случаев превратился в День университета, который ежегодно отмечался торжественными мероприятиями.

В общих чертах торжества проходили следующим образом. Празднование начинадось «благодарственным молебствием, при коем присутствовали все члены университета» ${ }^{23}$. Затем, как правило в пять

\footnotetext{
${ }^{18}$ Ibidem, s. 221.

${ }^{19}$ Харківський університет у спогадах його викладачів та вихованцієв, t. 1, Харків 2008, s. 35.

${ }^{20}$ А. І. Багалій, Вибрані твори, t. 3, s. 266-267.

${ }_{21}$ А. П. Рославский-Петровский, Об ученой деятельности Императорского Харьковского университета в первое десятилетие его существования, „Журнал Министерства Народного Просвещения" 1855, t. 87, nr 7, s. 2.

${ }_{22}^{2}$ Д. И. Багалей, Опьт истории Харьковского университета: В 2 m., t. 1, Харьков 1893-1898, s.190.

${ }^{23}$ Периодическое сочинение о успехах народного просвещения, С.-Петербург 1812, nr 33, s. 35; Описание торжества бывшего в императорском Казанском университете 15 сентября 1825 г., Казань 1825, s. 9.
} 
или шесть часов «по полудни», проводилось «торжественное ученое собрание» в зале университета, где «в присутствии губернских чинов, дворянства обоего пола», «почетнейшего духовенства и купечества» и «случившихся приезжих особ обоего пола» ${ }^{24}$, университетские профессора провозглашали свои «речи» на русском, латинском, немецком или французском языках. Приглашались на эту встречу «особыми билетами» ${ }^{25}$. Традиционно такие собрания сопровождались исполнением симфоний, увертюр и ораторий (особой популярностью в Харьковском университете начала XIX века пользовались произведения Гайдна), а университетские здания украшались илдюминацией. На этих мероприятиях зачитывались имена студентов, оказавших отличные успехи в науках, и им вручадись медали и книги ${ }^{26}$, эстампы и математические инструменты ${ }^{27}$, магистрам и кандидатам деканы «с установленною для сего церемониею» ${ }^{28}$ вручали дипломы, а новоявленным студентам - матрикулы и шпаги, оглашадись имена почетных членов университета. Акт заканчивался гимном «Боже, царя храни». На этом завершалась официальная часть торжества. ${ }^{29}$

Такая парадность производила особенное впечатление на студентов. Один из тех, кто получид шпагу во время торжественного акта, записал: «Дюбопытно было смотреть на радостные лица юношей, с каким самодоводьствием они выступади вперед при произнесении их имени, с каким восхищением они принимали из рук почтенных наставников приобретенные ими награды. Многие мои товарищи от восторга забывали себя, в том числе и я, вложивший шпагу в портупею на изворот. Да, какая разница удостоиться награды при тысячах зрителях, чем получать чин, сидя за письменным столом втихомолку» ${ }^{30}$. Не менее яркие воспоминания бывшего студента Харьковского университета В.Г. Масловича о торжественном акте 1810 г.: «К вечеру, в зал Университета приглашается все дворянство и почтеннейшие из граждан. Сначала учитель музыки с господами студентами, дюбителями музыки, пленяет посетителей или увертюрою или концер-

${ }^{24}$ Периодическое сочинение о успехах народного просвещения, С.-Петербург 1809, $\mathrm{nr}$ 22, s. 213; 1810, nr 25, s. 162-164; 1812, nr 33, s. 35.

${ }^{25}$ Периодическое сочинение о успехах народного просвещения, С.-Петербург 1811, nr $31 ; 1812$, nr 33, s. 35.

${ }^{26}$ Описание торжества бывшего в императорском Казанском..., s. 147.

${ }^{27}$ А. Д. Боровиков и его автобиографические записки, „Русская Старина” 1898, nr 9, s. 560 .

${ }_{28}$ Периодическое сочинение о успехах народного просвещения, С.-Петербург 1812, nr 33, s. 36.

${ }^{29}$ Zob. „Харьковские Губернские Ведомости” 1889, nr 16, s. 2.

${ }^{30}$ А. Д. Боровиков..., s. 560. 
том, потом избранные на сей раз из университетских членов, один за другим, между музыкою и угощеньем произносят сердечную благодарность покровителям просвещения и основателям храма наук. В заключение один из профессоров читает краткий годичный отчет об успешных действиях университета: об открытиях разных училищ, о пожертвованиях и приобретениях, о выбывших и вновь поступивших своих членах, о получивших докторские, магистерские и кандидатские достоинства, коим (надицо находящимся) и раздаются здесь, при звуке литавр, по заведенной форме, дипломы, о выбывших студентах на действительную службу и, наконец, о поступивших вновь. Сим последним ректор университета раздает шпаги» ${ }^{31}$. Описанный торжественный акт совпал с появлением кометы. Студенты, выходя после акта, салютовали ей шпагами.

Как и прежде, во время торжественных актов для публики открывались кабинеты и музеи. С годами «университетские акты» приобретали все большую популярность среди горожан. По словам историков города Харькова Д.И. Багалея И Д.П. Миллера на них, «стекался тогда весь Харьков» ${ }^{32}$.

И всё же, это лишь общее представление о торжествах. И дело не в том, что год от года менядись какие-либо элементы приведенного порядка празднования. Так, со второй половины 1820-х годов университеты стали отказываться от таких форм привлечения публики как угощения ${ }^{33}$. При описании торжественных актов уже не упоминается об обедах и затратах на угощение публики ${ }^{34}$. Очевидно, что какая-то часть публики была разочарована такими новациями. Отсутствие парадности на университетских актах не нравилось и некоторым профессорам. Так, профессор Московского университета П.С. Щепкин, посетив в 1828 г. Петербургский университет, записал: «На акте без малейшего перерыва (музыки не было по скудости университета) три

${ }^{31}$ Харківські спогади Масловича, „Записки історико-філологічного відділу [ВУАН]” 1927, ks. 13-14, s. 72.

${ }^{32}$ Д. И. Багалей, Д. П. Миллер, История города Харькова за 250 лет его существования (с 1655-го по 1905-й год), t. 2, Харьков 1912, s. 581.

${ }_{3}$ Л. Яновський, Харківський університет на початку свого існування (1805-1820), Харків 2004, s.113. Впрочем, это произощло далеко не сразу. Zob. O разрешении издержки в день торжественного собрания Харьковского университета, [w:] Сборник распоряжений по МНП, t. 1, С.-Петербург 1866, kol. 602-603. Заметим, что с этого времени обеды могли происходить у местного губернатора. Zob. Oписание торжества бывщего в имлераторском Казанском..., s. 9.

${ }^{34}$ Zob. nр. Из сообщения в печати о торжественном заседании Казанского университета 5 июля 1828 г., [w:] Материаль для биографии Н.И. Аобачевского, Москва-Денинград 1948, s. 273. 
профессора измучиди подным чтением без сокращений двух сочинений и одного отчета. На акте нет ни великолепия, ни приличия» ${ }^{35}$. Но, вероятно, что для определенной части местного общества университет со временем стал привлекателен уже сам по себе, как центр новых идей, средоточие интеллектуальной жизни. Все большее значение стали предавать не форме, но содержанию.

С годами не только значение «приманок» на университетские акты, но и официальной части торжеств будет снижаться. По мере того, как будет уведичиваться кодичество выпускников университетов, празднование дня того иди иного университета будет превращаться из мероприятия, имеющего важное государственное и местное общегородское значение, в событие скорее неформадьное, корпоративное, день своей alma mater ${ }^{36}$. Это не значит, что официальная часть празднования уйдет в прошлое. Совсем нет. Но большее значение приобретет именно неформальная встреча в этот день выпускников, студентов и преподавателей. В том числе это касадось и тех выпускников, которые проживади в других городах. Впервые такое явление будет отмечено в конце $1850-$ х годов ${ }^{37}$. В определенной степени оно может стать маркером нового этапа взаимодействия университета и общества: университет стал восприниматься как «свой».

При этом отмечена специфика собственно российского варианта саморепрезентации университетов. Публичные университетские церемонии несли на себе печать покровительства особого толка: официальные университетские театрализованные торжества были неизменно связаны с дичностью Государя (не случайно день рождения императрицы, 21 апреля, соединялся с годовщиной торжественного открытия Московского университета - 26 апреля, а окончание академического года приурочивадось к дню ее же восшествия на престол), непременным их атрибутом стали аллегорические композиции во славу императрицы - изображение Минервы (Афи-

\footnotetext{
${ }^{35}$ Павел Степанович Щепкин. Ввюержки из его писем, „Русский Архив” 1899, nr 6, s. 303.

36 Заметим, что и в европейской университетской культуре XIX в. наблюдается такая же тенденция: в торжественные для университета дни студенческий праздник получал все больше значимости. Zob. T. Becker, op.cit., s. 90, 92. „Пир на грани между публичным народным торжеством и закрытым званым вечером". (T. Becker, op.cit., s. 96) станет широко распространенным в праздничные дни и для российских университетов. k. 1-1v.

${ }^{37}$ Государственный Архив Российской Федерации, фонд 109, опис 1, дело 1042,
} 
ны), а затем (во времена Александра I) - фигуры Аполдона. Караул, ливрея швейцара - все это должно было придавать университету значимость учреждения государственной важности ${ }^{38}$. По мнению И.П. Кулаковой, феодальный дух «просвещенного покровительства» особого, русского толка еще долго витал над университетом ${ }^{39}$. Безусловно, особенности государственно-политического устройства не могли не оказывать вдияния на формы саморепрезентации университета. Однако следует также признать, что чинопочитание, иерархизация были типичными явлениями и для европейской традиции. Исследователи отмечают, что «как во Франции, так и у австрийских Габсбургов, борьба за почетные должности и за место на церемониях распространялось на все административные институты» ${ }^{40}$. Университеты Германии и в XIX в. организовывали собственные праздники в честь общенациональных торжеств, в число которых входиди годовщины восшествия на престол, день рождения императора и день основания империи ${ }^{41}$. Очевидно, что и в России саморепрезентация университета естественным образом была вплетена в систему сословно-иерархических отношений. Для провинциального российского дворянства такая возможность приобщения к государственному институту, который находится под Высочайшим покровительством, была тем более важной. Но следует подчеркнуть, что «приобщаться» к просвещению посредством участия в таких актах стали и незнатные горожане. Как писал С.П. Шевырев, «на глазах столицы наука давала, вместе со шпагою, дворянское достоинство людям всех званий. Этот обряд был выше, по своему значению, рыцарского обряда феодальных времен Запада» ${ }^{42}$ К тому же, следует иметь ввиду, что эти церемонии играли свою роль не только в системе властвования и установлении сословной иерархии, но и в процессе распространения новых культурных образцов. Как отмечает И.П. Кулакова, диспуты, речи, процедуры награждения, лекции с демонстрацией опытов и т.п. - все

${ }^{38}$ И. П. Кулакова, Университетское пространство и его обитатели. Московский университет в историко-культурной среде XVIII в., Москва 2006, s. 31-32.

${ }^{39}$ Ibidem, s. 35.

${ }^{40}$ Ю. Е. Ивонин, Универсализм и территориализм. Старая империя и территориальные государства Германии в раннее новое время 1495-1806, t. 2, сz. 2, Рейхстаги. Универсальное и национальное. Бюрократия и придворное общество. Секуляризация 18032. и конеи Священной Римской империи. Очерки, Москва 2009, s. 270.

${ }^{41}$ Т. Маурер, Университет и (его) город: новая перспектива для исследования истории российских университетов, [w:] Университет и город в России (начало ХХ века), Москва 2009, s. 75.

${ }^{42}$ С. П. Шевырев, История Московского университта, написанная к столетнему его юбилею. 1755-1855, Москва 1998, s. 195. 
это нетрадиционные, новые по сути своей ритуалы, которые игради особую роль в усвоении населением города нового культурного опыта. В XVIII в. участники ритуала-зрелища, несущего новую идею, неосознанно проделывали большую внутреннюю работу, постепенно вживаясь в новые культурные темы ${ }^{43}$.

Одновременно, мы можем говорить о специфике иного рода. Дело в том, что университеты в Российской империи не имели наследства в виде «корпоративной культуры». К тому же, они создавадись после полосы критики старого доклассического университета, а значит, какие-то формы и традиции могди восприниматься как архаичные представитедями самого университетского сообщества. Вот лишь один из примеров. Выпускник Казанского университета П.П. Перцов вспоминал: «В это время к нашей компании принадлежал бывший дерптский студент Неандер. Он рассказывал нам, как в немецких университетах, ежеди студенты пожелают выразить особенное внимание иди сочувствие какому-нибудь профессору, то из университета к дому профессора устраивается факедьное шествие (Fakel-zug). - Мы, пожелав изобразить из себя европейских студентов, решили тоже устроить факельное шествие к дому Пушкина [попечителя М.Н. Мусина-Пушкинана. - С.П.] на Покровской улице...». Ректор Н.И. Добаческий тогда отговорид студентов от подобного «выражения чувств», мотивируя это тем, что «у нас в русских университетах не приняты подобные факельные шествия, да и подиция не позволит идти по улице с зажженными факелами». Он посоветовал студентам собраться в полной мундирной форме и расположиться в два ряда вдоль парадной лестницы ${ }^{44}$. Пример достойный того, чтобы порассуждать о варианте адаптации новых культурных образцов в России.

Определёнными вехами на пути формирования университетских традиций стали юбилеи университета, во время празднования которых обозначенные выше формы саморепрезентации получали еще более яркое воплощение.

Запоминающимся событием не только в жизни университета, но и города, стало празднование Московским университетом своего 50-летнего юбилея (30 июня 1805 г.). Предварительно 28 июня было разослано напечатанное на латинском и русском языках приглашение к любителям наук, чтобы те приняли участие в полувековом юбилее университета. Сочинял его профессор Буле. Показав историческое

${ }^{43}$ И. П. Кулакова, op.cit., s. 198.

${ }^{44}$ Материаль для биографии Аобачевского, s. 630. 
значение университетов вообще, он указал на заслуги Московского, и приглашал в заключение к торжеству, предлагая его программу ${ }^{45}$. 30 июня, утром в 8 часов, члены университета собрались в большой аудитории, откуда пошли в университетскую церковь. По полудни в 5 часов «хором благодарных Московских Муз к Августейшим своим Питателям и Покровителям» открылся торжественный акт. После чего выступил ректор и прозвучало шесть речей от профессоров, представляющих все отделения. В том числе проф. Рейнгард произнес речь на латинском языке «О плодах, каких можно ожидать от университетов основанных». После речей, в заключение торжества, «провозглашены были производства в ученые достоинства и степени», некоторые студенты были награждены медадями, 27 воспитанников гимназии произведены в студенты. В 10 часов вечера публике была представлена иллюминация: «Пылали 6 пирамид. Между ними видна была прозрачная картина, изобретенная славным живописцем Тончи. Здесь Елизавета I, в образе Минервы, попирала косу Сатурнову... Гений Александра I подавал масличную ветвь России в знак мира, а Минерва указывала ей на вензель Императора» ${ }^{46}$. Е.Ф. Тимковский вспоминал: «Торжество ведиколепное, при многодюдном стечении знаменитостей московских, украшенное стройными хорами Данилы Кашина, кои превосходно пели университетские певчие с аккомпанировкою прекрасной музыки графа Ал. Кир. Разумовского, все это восхитило меня до небес» ${ }^{47}$.

Харьковскому университету не удалось отпраздновать ни свое 50-летие, ни даже, в полной мере, 100-летие со дня создания. Так долго подготавдиваемый и так ожидаемый столетний юбилей Харьковского университета был оттеснен на второй план реводюционными событиями 1905 года. Вначале, «в виду событий на Дальнем Востоке», Совет постановил ходатайствовать перед высшим начадьством о переносе торжества с 17-го января на 15 сентября 1905 г. ${ }^{48}$ В последующем в дитературе появилась версия о том, что празднование отложиди «дабы связать с ним и открытие памятника В.Н.Каразину, в дан-

45 Традиция приглашать к своим торжествам «весьма затейливыми объявлениями, на больших листах, печатанных по-латыни и по-русски», каждый раз по-новому, зародилась в Московском университете уже в первые годы его существования. С. П. Шевырев, оp.cit., s. 67.

${ }^{46}$ Ibidem, s. 359-361.

${ }^{47}$ Е. Ф. Тимковский, Московский университет в 1805-1810 г2. Из воспоминаний, [w:] Московский университет в воспоминаниях..., s. 60.

${ }^{48}$ Державний Архів Харківської Області, фонд 45, опіс 1, справа 3053, k. 1. 
ный момент ещё не готового» ${ }^{49}$. Очевидно, власти резонно опасались превращения праздника в беспорядки. Известно, что на 17-е января готовился банкет в зале Дворянского собрания. Учитывая настроения студенчества и подитически активных кругов харьковской общественности, местная администрация закрыла Дворянское собрание и запретила банкет. Тогда публика в количестве до 500 чедовек ворвалась в оперный театр и устроила там митинг, требуя Учредительного собрания ${ }^{50} .21$ января Совет университета постановид «ходатайствовать о приостановке учебных занятий на две недели». Позже им была принята «Записка», в которой данное «ходатайство» объяснялось «событиями политической и общественной жизни» ${ }^{1}$. Октябрь 1905 г. в Харькове был ознаменован баррикадами на Университетской улице.

Как известно, после установления советской власти, университеты подвергдись основательному реформированию. В Украине исчезло даже само название «университет». Университеты были объявлены не тодько орудием кодониадьного угнетения, но и «цитаделями» буржуазно-феодальных порядков. В ходе так называемой «реорганизации» все они были существенно перепрофилированы. По сути, они превратидись в специадизированные педагогические учебные заведения, состоялось отделение «научной части» от учебной, были введены дискриминационные меры в отношении состава студентов и преподавателей, связанные с их социальным происхождением и политическими настроениями, на некоторое время перестала существовать система ученых степеней, государственное начало стало довлеющим, в системе управления утвердился принцип «единоначадия». Старые традиции быди преданы забвению, поскодьку острой критике подверглась сама идея университета.

История советских университетов в значительной мере созвучна с тем, что наблюдалось в это же время и в Германии. В этом плане мы можем говорить об общих тенденциях в развитии университетов. Процитируем Ф. Рингера: «Посредством принципа фюрерства было уничтожено университетское самоуправление. Идеи научной свободы и объективности были официально отвергнуты. Третий рейх

49 Д. И. Багалей, Как готовится Харьковский университет к своему столетнему юбилею?, t. 20, „Сборник Харьковского Историко-Филологического Общества”, Харьков 1911, s. 446. Памятник В.Н. Каразину был открыт в июне 1907 г.

${ }^{50}$ Харьков и Харьковская губерния в первой русской революичи 1905-1907 годов. Сборник документов и материалов, Харьков 1955, s. 55.

51 Записка Совета Императорского Харьковского университета по вопросу об условиях, при которых возможно достижение нормального течения университетской жизни, Харьков 1905, s. 1. 
не нуждался в «непрактичной» учености, классическом гуманизме и «аполитичности» и не желал терпеть в университетах «академический пролетариат». Были введены квоты на поступление с особенно суровыми ограничениями для женщин. ... Наибольшие потери понесли теоретические дисциплины, такие как философия; узкопрофессиональные предметы пострадали не так сильно. Одновременно с этим у абитуриентов стали требовать сертификаты о примерном поведении и политической благонадежности. Будущие школьные учителя и университетские преподаватели обязаны были демонстрировать неразрывную связь с нацией в трудовых лагерях и на политических собраниях. Высшее образование утратило свою сугубо интеллектуальную и научную сущность» ${ }^{52}$. Все сказанное можно охарактеризовать не иначе как кризис классического университета.

Впрочем, если наблюдать определенную эволюцию в развитии советских университетов, то можно заметить, что с 1933 г., когда был принят указ о воссоздании государственных университетов в Украине, начнется и обратный процесс постепенного возрождения некоторых университетских традиций. С этого времени опять стали вспоминать о достижениях университета, готовиться к юбилеям. Впрочем, это не означало, что возродились старые взгляды на университет и освященные столетиями формы саморепрезентации университетов. По сравнению с дореволюционными временами существенно изменилось и положение университета, и взгляды на его историю, и сами университетские традиции. Произошел разрыв в университетской памяти. Так, создание университетов объяснялось задачей укрепления монархии, характерными явдяются высказывания о «режиме крепостничества», «атмосфере гонений» и т.п. Соответствующим был и вывод: «Великий Октябрь смыл всю реакционную контрреволюционную нечисть, которая была в университете, превратил его в очаг науки и культуры для трудящихся масс» ${ }^{53}$. Принципиально новыми выглядят и формы саморепрезентации университета. Так, к 130-летию Харьковского университета были запланированы «факультетские вечера с участием рабочих», «физкультурная олимпиада», «посылка делегаций в университетские города», «организация звездного лыжного пробега по Харьковской области для приглашения колхозников» и т.п. ${ }^{54}$

52 Ф. Рингер, Закат немецких мандаринов: Академическое сообщество в Германии. 1890-1933, пер. с англ. Е. Канищевой и П. Гольдина, Москва 2008, s. 526-527.

53 „Вісті" 1935, nr 296, s. 3.

${ }^{54}$ Музей истории Харьковского национального университета имени В.Н. Каразина, фонд 7, опис 14, папка 5-А. 
И все же традиционная университетская культура удивительным образом возрождалась из пепла, проявляя невероятную живучесть. Признаки возрождения «университетского духа» можно наблюдать уже в период празднования 100-летия Московского и 150-летия Харьковского и Казанского университетов.

Празднования этих юбилеев предусматривало открытие выставок, проведение торжественных заседаний, доклады и речи, научные конференции. Важно отметить, что университетским юбилеям тогда был придан характер городских праздников. Здания университетов, привокзальные площади, некоторые улицы и парки были соответствующим образом оформлены транспарантами. Для гостей университетов были организованы экскурсии по городу и его музеям. Следует особо подчеркнуть, что в советское время университетам стали вручать правительственные награды - ордена, которые прикреплядись к университетским знаменам, торжественные собрания непременно посещали высокие государственные деятели, от руководителей государства и высших государственных органов зачитывались соответствующие приветствия.

Последующие юбилеи уже не имели такого размаха, хотя, казалось бы, проходили в более благоприятных условиях. Важно отметить, что с середины 1960-х годов, например, возродилась традиция отмечать день рождения Харьковского университета торжественным заседанием Совета в январе. Дата торжественного заседания не всегда совпадала с днем открытия университета 17(29) января, поскольку по расписанию работы Учёный совет собирался по пятницам. Однако, важен сам принцип. Впрочем, возрождение университетских традиций было непоследовательным. Зримым выражением такой «половинчатости» стал памятник основателю университета В.Н.Каразину (воздвигнут в 1907 г. и перенесен в начале 1960-х годов к новому корпусу), установленный за углом фасада университетского здания. $\mathrm{K}$ тому времени на памятнике давно уже быди сбито слово «императорский» применительно к основанному университету. В 1972 г. возник музей истории университета. Тогда это был один из первых такого рода музеев. Удивительно, но до этого времени такое «место памяти» просто отсутствовало во многих советских университетах (например, в Московском государственном университете имени М.В. Домоносова такой музей откроется дишь в 1995 г.).

Хотя Казанский университет получил имя Денина уже в 1924 г., но собственно «ленинским» он стал позже. Тот факт, что здесь начинал учиться В.И. Аенин, позволил ему претендовать на высокое, почти сакральное место в пространстве советской культуры. Не удиви- 
тельно, что в Казанском университете именно к 100-летию В.И. Денина в начале 1970-х годов была завершена программа возрождения исторических интерьеров университета, придания особого акцента преемственности (пусть и «революционной») поколений университетских людей. Бывший храм науки стал живым ленинским мемориалом ${ }^{55}$.

Активное восстановление многих традиционных форм саморепрезентации университетов наблюдается в 1980-х годах, а в постсоветский период становится повсеместным. Так, с 1980 г. благодаря Клубу ученых МГУ и Московскому дому ученых в Московском университете возобновится празднование Татьяниного дня. В начале 1990-х годов этот университет стал официально отмечать его как ежегодный праздник.

Вообще, следует заметить, что с начала 1990-х годов начался новый этап собственно в истории самих университетов. Развитие рыночных отношений и коммерциализация образования стали фактором не только структурных перемен, но и реализации многих имиджевых проектов. На этом поле развернулась настоящая борьба за лидерство на региональном образовательном пространстве раздичных высших учебных заведений, которые также претендуют на «универсальность» и стремятся подкрепить свои претензии раздичными способами.

Усиление конкуренции на образовательном пространстве привело к тому, что стали подвергаться пересмотру устоявшиеся мнения одатах основания тех или иных университетов. Наиболее резонансной стала дискуссия о времени возникновения Петербургского университета, которая породила спор о «первородстве» между Московским и Петербургским университетами (в результате, в 1994 г. в Петербурге отпраздновали «новый», 270-летний юбилей $)^{56}$. Аналогичную ситуацию можно наблюдать и в Харькове, где некоторые высшие учебные заведения в начале XXI века, вопреки историческим данным, также заявили о своём приближающемся 200-летнем юбилее (харьковские Юридическая академия, Медицинский, Фармацевтический и Педагогический университеты). Руководство раздичных учебных заведений старается использовать юбилеи, чтобы получить определенные преференции от центральной власти (дополнительные финансы, награ-

${ }^{55}$ Е. А. Вишленкова, С. Ю. Малышева, А. А. Сальникова, История университета как история памяти корпорациии, „Ab Imperio” 2004, nr 3, s. 296.

${ }^{56} \mathrm{Zob}$. А. Ю. Андреев, О начале университетского образования в Санкт-Петербурге, „Отечественная История” 1998, nr 5; И. П. Кулакова, Спор о первородстве: 275 лет Санкт-Петербургскому университету?, „Вопросы Истории Естествознания и Техники" 1999, nr 3. 
ды, особые нормы и т.п.), но, одновременно, также дополнительные преимущества в конкурентной борьбе за абитуриентов и благоскионность региональных властей. Особую актуальность в этих условиях приобрел вопрос о вариантах репрезентации университетской истории через раздичные устойчивые формы визуализации. Обычными стали театрализованные представления при посвящении в студенты, шествие в мантиях профессоров и выпускников университета. Ярким зрелищем во время празднования 200-летия Харьковского университета стали эстафета передачи факела, символизирующего «огонь знаний» и «живая цепь» из студентов, преподавателей и выпускников, протянувшаяся через всю центрадьную часть города.

Возде вузов появились свои памятники, которые должны создать соответствующий его образ и доказать его «древность». Так, в Харькове возде основного корпуса Национального педагогического университета имени Г.С. Сковороды появился памятник выдающемуся украинскому философу (хотя он жил в XVIII веке и преподавал в Харьковском коллегиуме). Памятник Ярославу Мудрому был установлен возде Национального юридического университета, носящего имя киевского князя. Возле нового здания Национального фармацевтического университета установлен памятник «Фармация в веках», одним из элементов которой является фигура средневекового аптекаря в университетской мантии.

Вполне очевидно, что подготовка и празднование юбилеев университетов Восточной Европы продемонстрировали значение вопроса о региональных образовательных системах и роли в них классических университетов.

Таким образом, можно утверждать, что юбилейная университетская культура на Востоке Европе претерпела определенную эволюцию. Первоначально это были попытки во всем подражать традициям европейских университетов. Впрочем, уже эти попытки имели свою специфику, связанную с тем, что в Российской империи университеты сразу создавались как государственные, в них было слабо развито корпоративное начало, а корпоративная культура не имела глубоких корней. В советский период произошел «разрыв» в университетской истории, поскольку ожесточенной критике подверглась сама идея университета, а многие формы саморепрезентации были отвергнуты или существенно видоизменены. Хотя в последующем многие традиции стали восстанавдиваться (и этому способствовади именно празднования юбилеев), однако идеологические и политические факторы предопределиди специфику юбилейных торжеств. В постсоветское время многие университеты стали практиковать во время 
торжественных мероприятий ритуалы, свойственные «старым» университетам Европы: мантии, шествия, церемонии. На востоке Европе такие действия часто вступают в противоречие с состоянием университетской культуры и выглядят несколько искусственными. Большей частью они объясняются стремлением руководства университетов получить преимущества в конкурентной борьбе за различные ресурсы. Помимо того, что многие специализированные высшие учебные заведения получили название «университет» (что само по себе размывает идею университета), повсеместно начали пересматриваться даты создания этих учебных заведений, а также организовываться выдуманные юбилеи. Все это способствует тенденции к нивелированию роли университетов в региональных образовательных системах. Такого рода борьба за «сферы влияния» воспринимается многими как проявление очередного кризиса университета.

\section{BIBLIOGRAFIA:}

Becker T., Jubiläen als Orte universitärer Selbstdarstellung. Entwicklungslinien des Universitätsjubiläums von der Reformationszeit bis zur Weimarer Republik, [w:] Universität im öffentlichen Raum, Basel 2008, s. 77-107.

Ditzhuyzen van R., Selbstdarstellung der Universität. Feiern und Zeremoniell am Beispiel der Doktorpromotionen, [w:] Universität im öffentlichen Raum, Basel 2008, s. 45-77.

А. Д. Боровиков и его автобиографические записки, „Русская Старина” 1898, nr 9.

Андреев А. Ю., О начале университетского образования в Санкт-Петербурге, „Отечественная История" 1998, nr 5.

Андреев А. Ю., Российские университеты XVIII-первой половины XIX века в контексте университетской истории Европь, Москва 2009.

Багалей Д. И., Как готовится Харьковский университет к своему столетнему юбилею?, t. 20, „Сборник Харьковского Историко-Филологического Общества”, Харьков 1911.

Багалей Д. И., Опьт истории Харьковского университета: В 2 m., t. 1, Харьков 1893-1898.

Багалей Д. И., Харьковские университетские торжества, Харьков 1892.

Багалей Д. И., Миллер Д. П., История города Харькова за 250 лет его существования (с 1655-20 по 1905-й год), t. 2, Харьков 1912.

Багалій Д. І., Вибрані твори, т. 3, Харків 2004.

Вишленкова Е. А., Малышева С. Ю., Сальникова А. А., История университета как история памяти корпорацุии, „Ab Imperio” 2004, nr 3, s. 271-310.

Записка Совета Императорского Харьковского университета по вопросу об условиях, при которых возможно достижение нормального течения университетской жизни, Харьков 1905.

Ивонин Ю. Е., Универсализм и территориализм. Старая империя и территориальные государства Германии в раннее новое время 1495-1806, t. 2, сz. 2., Рейхстаги. Универсальное и нацииональное. Бюрократия и придворное общество. Секуляризациия 18032. и конеи Священной Римской империи. Очерки, Москва 2009. 
Из сообщения в печати о торжественном заседании Казанского университета 5 июля 1828 г., [w:] Материаль для биографии Н. И. Лобачевского, Москва-Ленинград 1948.

Кулакова И. П. Спор о первородстве: 275 лет Санкт-Петербургскому университету?, „Вопросы Истории Естествознания и Техники” 1999, nr 3, s. 57-92.

Кулакова И. П., Университетское пространство и его обитатели. Московский университет в историко-культурной среде XVIII в., Москва 2006.

Маурер Т., Университет и (его) город: новая перспектива для исследования истории российских университетов, [w:] Университет и город в России (начало ХХ века), Москва 2009.

Миклашевський Й. М., Музична і театральна культура Харкова XVIII-XIX ст., Київ 1967.

Московский университет в воспоминаниях современников, Москва 1989.

Описание торжества бывщего в императорском Казанском университете 15 сентября 1825 г., Казань 1825.

Павел Степанович Щепкин. Выдержки из его писем, „Русский Архив” 1899, nr 6.

Периодическое сочинение об успехах народного просвещения, Санкт Петербург 1805, nr 12. Периодическое сочинение о успехах народного просвещения, Санкт Петербург 1809, nr 22.

Периодическое сочинение о успехах народного просвещения, Санкт Петербург 1810, nr 25.

Периодическое сочинение о успехах народного просвещения, Санкт Петербург 1811, nr 31.

Периодическое сочинение о успехах народного просвещения, Санкт Петербург 1812, nr 33.

Петухов Е. В., Императорский Юрьевский, бывиий Дерптский, университет за сто лет его сущзествования (1802-1902), t. 1, Юрьев 1902.

Рингер Ф., Закат немеиких мандаринов: Академическое сообщество в Германии 18901933, Пер. с англ. Е. Канищевой и П. Гольдина, Москва 2008.

Рославский-Петровский А. П., Об ученой деятельности Императорского Харьковского университета в первое десятилетие его существования, „Журнал Министерства Народного Просвещения" 1855, t. 87, nr 7.

Тимковский Е. Ф., Московский университет в 1805-1810 г2. Из воспоминаний, [w:] Московский университет в воспоминаниях современников, Москва 1989.

Уваров П. Ю., Университеть Российской империи глазали медиевиста (в защиту «идола истоков»), „Диалог со временем" 2001, nr 7.

Харківські спогади Масловича, „Записки історико-філологічного відділу [ВУАН]”, 1927, ks. 13-14.

Харківський університет у спогадах його викладачів та вихованців, t. 1, Харків 2008.

Харьков и Харьковская губерния в первой русской революичии 1905-1907 годов. Сборник документов и материалов, Харьков 1955.

Шевырев С. П., История Московского университета, написанная к столетнему его юбилею. 1755-1855, Москва 1998.

Яновський А., Харківський університет на початку свого існування (1805-1820), Харків 2004. 


\section{ABSTRACT:}

The aim of the present article is to reflect upon various forms of self-presentation of universities in Eastern Europe, with special attention devoted to so-called "university jubilee culture". It appears that this phenomenon came into being in Eastern Europe as a result of traditions present in renowned universities of Western Europe. During the Soviet times the tradition of jubilees at universities changed to a great extent and the revival of a number of forms of self-presentation nowadays has been conditioned by a number of factors. These comprise many differentiating features, which may be a sign of crisis in university milieus.

Key words: university, jubilee, Eastern Europe, Soviet Union

\section{NOTA O AUTORZE:}

Sergij Posokhov - profesor doktor habilitowany historii, dziekan Wydziału Historycznego Uniwersytetu Narodowego im. W. N. Karazina w Charkowie, stypendysta Niemieckiego Instytutu Historycznego w Moskwie. Autor wielu prac za zakresu dziejów oświaty w XIX i początku XX w. w Imperium Rosyjskim. e-mail: istfac@univer.kharkov.ua 